\section{Expert Opinion}

1. Background

2. Medical need

3. Existing treatment

4. Current research goals

5. Scientific rationale

6. Competitive environment

7. Conclusions

8. Expert opinion

\title{
Anti-endothelin drugs in solid tumors
}

\author{
Antonio Russo ${ }^{\dagger}$, Giuseppe Bronte, Sergio Rizzo, Daniele Fanale, \\ Francesca Di Gaudio, Nicola Gebbia \& Viviana Bazan \\ ${ }^{\dagger}$ Università di Palermo, Section of Medical Oncology, Department of Surgical and Oncological \\ Sciences, Via del Vespro 129, 90127 Palermo, Italy
}

Importance of the field: The endothelin (ET) axis, which includes the biological functions of ETs and their receptors, has played a physiological role in normal tissue, acting as a modulator of vasomotor tone, tissue differentiation and development, cell proliferation and hormone production. Interestingly, it also functions in the growth and progression of various tumors. Several researchers have identified the blockade of the ET-1 receptor as a promising therapeutic approach.

Areas covered in this review: The clinical investigation of an orally bioavailable ET antagonist, atrasentan, in prostate cancer, is encouraging. In this neoplasia, it has shown antitumor activity, bone metastasis control and amelioration of cancer-related pain but improvement in time to progression and overall survival has still not been demonstrated. The clinical trials of other ET antagonists are reported. Literature research was performed by Pubmed and Pharmaprojects.

What the reader will gain: A comprehensive view about the use of atrasentan in the treatment of castration-resistant prostate cancer (CRPC) is provided together with the scientific rationale based on the function of ET and its receptor in various cancer development mechanisms.

Take home message: Atrasentan seems to be active in CRPC, although strong scientific evidence is still to be found. Interesting clinical findings regard zibotentan.

Keywords: atrasentan, endothelins, prostate cancer, zibotentan

Expert Opin. Emerging Drugs (2010) 15(1):27-40

\section{Background}

The endothelins (ETs), discovered by Yanagisawa in 1988, are a family of small peptides, well conserved from the evolutionary aspect, with multiple roles in a variety of tissues [1]. Initially, ET was thought to be important in cardiovascular homeostasis; ET receptor antagonists and endothelin-converting enzyme (ECE) inhibitors have, therefore, been developed mostly for the treatment of cardiovascular diseases. Molecular biology has also provided valuable information about ET, including evidence that the ET system plays an important role in the early development of the neural crest and, thus, in the formation of organs [2].

At present, the ET system, which comprises ETs, their receptors and the enzymes of ET biosynthesis and degradation, is thought to have a role in the pathophysiology of many tumor types, including prostatic, pulmonary, cervical, endometrial, ovarian, colorectal, breast, bladder, renal and brain tumors, Kaposi's sarcoma, bone metastases and melanoma [3-5]. In mammals, the ETs comprise a family of three 21 aminoacid peptides, ET-1, ET-2 and ET-3, whose structure consists of a single $\alpha$-helix and two intramolecular disulfide bonds. Whereas ET-1 and ET-2 have similar structures, ET-3 differs in structure at 6 of 21 amino acids. ET-1 is not organ-specific and is expressed primarily by endothelial cells, whereas ET-2 is mainly present in the 
intestine and kidney, and ET-3 is mainly localized in the brain and to a lesser extent in gastrointestinal stromal cells and lung epithelial cells [4].

The ETs are encoded by distinct genes and are regulated at the level of mRNA transcription and post-transcription [1]. The primary translation product of the mRNA of ET- 1 gene is the 212-aa prepro-ET-1. Active ET-1 is synthesized from a biologically inactive 38-aa precursor, Big ET-1, by an unusual hydrolysis of the $\operatorname{Trp} 21-\mathrm{Val} 22$ bond by a metalloprotease with intracellular and membrane bound isoforms, known as the ECE-1 [6,7]. The mature peptide is continuously released from vascular endothelial cells by the constitutive pathway, producing intense constriction of the underlying smooth muscle and contributing to the maintenance of endogenous vascular tone. Several studies of various malignancies have revealed that members of the ET family are produced by several epithelial tumors, in which they act as autocrine and/or paracrine growth factors. ET-1 is the most common circulating form of ET [8].

ETs are powerful vasoconstrictive peptides that exert their effects through two specific heptahelical GPCR subtypes: the endothelin A receptor $\left(\mathrm{ET}_{\mathrm{A}} \mathrm{R}\right)$ specific for ET-1 and ET-2 and the nonspecific endothelin $\mathrm{B}$ receptor $\left(\mathrm{ET}_{\mathrm{B}} \mathrm{R}\right)[1,9,10]$. The ET receptors share about $59 \%$ similarity in the primary structure. The $\mathrm{ET}_{\mathrm{A}} \mathrm{R}$ selectively binds ET-1 and ET-2, whereas the $\mathrm{ET}_{\mathrm{B}} \mathrm{R}$ binds all three ET forms with similar affinity. While the $\mathrm{ET}_{\mathrm{A}} \mathrm{R}$ primarily mediates vaso-/bronchoconstriction, mitogenesis, antiapoptosis, matrix formation, acute and neuropathic pain, the $\mathrm{ET}_{\mathrm{B}} \mathrm{R}$ mediates inflammatory pain and vasodilatation and has further been proposed to contribute to clearance of ET as well as to autoinduction of ET-1 [11]. Although the $\mathrm{ET}_{\mathrm{B}} \mathrm{R}$ may also mediate vasoconstriction, this subtype, which is primarily situated at the plasma membrane of endothelial cells, is first of all considered causing transient NO-mediated vasodilatation. The $\mathrm{ET}_{\mathrm{B}} \mathrm{R}$ shares several intracellular signaling pathways with the $\mathrm{ET}_{\mathrm{A}} \mathrm{R}$; however, unlike $\mathrm{ET}_{\mathrm{A}}$ receptor-dependent effects, $\mathrm{ET}_{\mathrm{B}} \mathrm{R}$-dependent phenomena are shorter lasting and reversible. ET receptor interacts with heterotrimeric $\mathrm{G}$ proteins. After ligand binding, $\mathrm{ET}_{\mathrm{A}} \mathrm{Rs}$ become internalized and undergo receptor recycling followed by relocation to the cell membrane, whereas $\mathrm{ET}_{\mathrm{B}} \mathrm{Rs}$ can be translocated to the lysosomal compartment for degradation [12] or translocated to nuclear membranes for further signaling events [13]. ETs and ET receptors are ubiquitously expressed and regulate a wide range of physiological and pathophysiological functions, such as cardiovascular, mitogenic and neuroregulatory events, hormone production and placental development [14].

ET-1 production is stimulated by cytokines (IL-1h), growth factors (TNF- $\alpha$, TGF-h and platelet-derived growth factor (PDGF) and major signals of cardiovascular stress, such as vocative agents (angiogenesis II, norepinephrine, vasopressin and bradykinin), thrombin, mechanical stress and hypoxia. Prostacyclin, NO and atrial natriuretic peptide are the predominant effectors of negative feedback mechanisms [15].

\section{Medical need}

Nearly all patients with advanced prostate cancer are sensitive to androgen ablation therapy. However, the effect of this treatment on disease progression is temporary. These patients ultimately become resistant to androgen ablation and are then classified as having castration-resistant prostate cancer (CRPC). To date, chemotherapy is the main option for this disease. Docetaxel represents the best tolerated and effective agent of treating it.

There has been great interest regarding the possibility of using this drug for the treatment of even elderly patients, because prostate cancer apparently occurs more frequently in older men. An intravenously delivered chemotherapeutic agent with high incidence of hematological toxicity, even if better tolerated than other drugs with the same clinical indication, such as docetaxel, may hinder the accessibility of comorbid patients. For several years, oncologists have been trying to find new agents with minimal toxicity to be administered per os.

Another hurdle for these patients is the development of resistance to docetaxel. When CRPC patients progress after first-line therapy, there are only a few options available for their treatment. New types of therapy are required in this patient setting. The effect of ET receptor antagonists on angiogenesis might be exploited to overcome taxane resistance.

\section{Existing treatment}

Treatment with hormone therapy or chemotherapy is the standard option for patients with CRPC. After progression on both a luteinizing-hormone-releasing hormone agonist and antiandrogen, the withdrawal of antiandrogen therapy results in an antiandrogen withdrawal response in $25-50 \%$ of patients. Secondary hormone medications, including ketoconazole and hydrocortisone, could induce a clinical response in $\sim 25 \%$ of patients. This benefit lasts for only a short time, with a mean duration of 4 months. For this reason, chemotherapy is considered the main choice for such patients. The development of novel therapeutic agents for the treatment of CRPC is still to be explored in this patient population.

Combination chemotherapy regimens involving agents that affect microtubule integrity appear to have activity with tolerable adverse effects. In particular, combination regimens including taxanes seem the most promising treatment, achieving $>50 \%$ response rates. However, the median duration of response is limited to $\sim 6$ months. Additional survival benefits reported in Phase II trials have not yet been confirmed in Phase III randomized trials.

Because of the increasing proportion of patients included in earlier application of taxane-based chemotherapy, there is an ever enlarging subset of patients with disease progression who remain viable candidates for additional therapy. To date, we lack enough data from clinical trials to guide decision making, although clinical investigation is ongoing for this subset of 
patients. Usually, CRPC patients previously treated with first-line chemotherapy are classified into two groups: mitoxantrone-treated patients, for whom the utility of taxanes as second-line therapy should be considered, and taxanetreated patients, for whom the activity of retreating with taxanes, mitoxantrone or other microtubular targeted agents is under investigation.

ET receptor antagonists studied for cancer treatment are not yet marketed.

A previous US registration submission as Xinlay for the treatment of metastatic CRPC received a non-approvable letter (Scrip Daily Online, 17 October 2005, S00899072). Abbott decided not to pursue further registration of astrasen$\tan$ for this indication (direct communication, Abbott, 24 August 2007). It had US fast-track status for prostate cancer (press conference, Abbott, 6 February 2001).

Regarding Zibotentan, European and US filings for the treatment of CRPC are expected in 2011 (company pipeline, AstraZeneca, 31 January 2008).

\section{Current research goals}

The main goals of treatment with ET receptor antagonists for CRPC patients include:

- Availability of agents with minimal or manageable toxicity and orally bioavailable to extend applicability of anticancer treatment even for elderly and comorbid patients.

- Efficacy on cancer-related pain and bone metastases complications, which are the most frequent factors impairing quality of life.

- Applicability also in nonmetastatic CRPC to improve both progression-free survival and overall survival and to delay major complications deriving from clinically evident metastases.

The great hope of the researchers regards the prospect of using ET receptor antagonists even in other malignancies. Until now, no clear evidence has been provided for activity of these agents in different cancers. A better understanding of the biological mechanisms of their action will make it possible to investigate them in a more suitable patient setting.

\section{Scientific rationale}

\subsection{Role of ET-1 in cell growth}

ET-1 is a powerful vasoconstrictor with mitogenic or comitogenic properties, which stimulates proliferation in vitro of fibroblasts, renal mesangial cells, smooth muscle and several tumor cell lines, including colorectal cancer [16-20]. Studies involving colorectal, ovarian and prostate cancers suggest that the receptor responsible for the ET-1 mitogenic action is $\mathrm{ET}_{\mathrm{A}}$, which is probably upregulated. Activation of the $\mathrm{ET}_{\mathrm{A}} \mathrm{R}$ by ET-1 mediates a signaling cascade, which promotes tumor cell growth, synergizing with other growth factors to cause cell proliferation (Figure 1). $\mathrm{ET}_{\mathrm{A}}$ interacts with and activates a $G$ protein that triggers a parallel activation of several signal transducing pathways. This interaction can in fact activate multiple signal transduction pathways including phospholipase $\mathrm{C}$ activity with a consequent increase in intracellular $\mathrm{Ca}^{2+}$ levels, PKC, phosphati-dylinositol 3-kinase and MAPK [21]. $\mathrm{ET}_{\mathrm{B}} \mathrm{R}$-mediated coupling in choriocarcinoma cell lines leads to the activation of the Ras/Raf-MAPK pathway [22]. ET-1 causes EGFR transactivation which is partly responsible for MAPK activation by a ligand-dependent mechanism involving a non-receptor tyrosine kinase, such as Src. Recent work has reported that a specific $E_{\mathrm{A}} \mathrm{R}$ antagonist can reduce the EGFR transactivation [14,23-25].

The phenotypic change of vascular smooth muscle cells in culture is concommitantly associated with a change in the ET receptor subtype which potentiates mitogenic activity. This suggests that the switching of the ET receptor subtype from A to $\mathrm{B}$ during phenotypic change may contribute to a certain extent to the development of vascular lesions [26].

ET-1 promotes DNA synthesis and cell proliferation in various epithelial tumor cells, including prostate, cervical and ovarian cancer cells. Synergistic interactions with other growth factors, including EGF, basic fibroblast growth factor (bFGF), insulin, IGF, PDGF, TGFs and IL-6, intensify mitogenic activity [27].

\subsection{Role of ET-1 in angiogenesis}

Angiogenesis, the formation of new vessels from existing vasculature, is an important early event in tumor progression which begins in premalignant lesions. VEGF and bFGF are the principal regulators of neovascularization. During the formation of new blood vessels, endothelial cells are stimulated to release proteases, such as MMP-2, in order to migrate, proliferate and invade surrounding tissue and form capillaries. Initiation of angiogenesis is controlled by different regulators including local hypoxia, which activates the expression of angiogenic factors that can stimulate endothelial cell growth [28]. Activation of $\mathrm{ET}_{\mathrm{A}} \mathrm{R}$ by $\mathrm{ET}-1$ promotes tumor growth and progression by stimulating the production of the key angiogenic factor VEGF in response to hypoxia. ET-1 regulates various stages of neovascularization, including endothelial cell proliferation, migration, invasion, protease production and tube formation, and also stimulates neovascularization in vivo [29]. ET-1 increases VEGF mRNA expression and VEGF protein levels in a dose- and time-dependent manner, and does so to a greater extent under hypoxia. ET-1 stimulates VEGF production through the hypoxia-inducible factor HIF- $1 \alpha$ and this mechanism might be responsible for increasing tumor angiogenesis. Degradation of HIF- $1 \alpha$ is in fact reduced in ET-1-treated ovarian carcinoma cells under both hypoxic and normoxic conditions, indicating that the induction of HIF- $1 \alpha$ protein production by ET-1 is due to enhanced HIF-1 $\alpha$ stability. After $\mathrm{ET}_{\mathrm{A}} \mathrm{R}$ activation by ET-1, HIF-1a protein levels are increased, the HIF-1 transcription complex is formed and binds to the hypoxia-responsive 

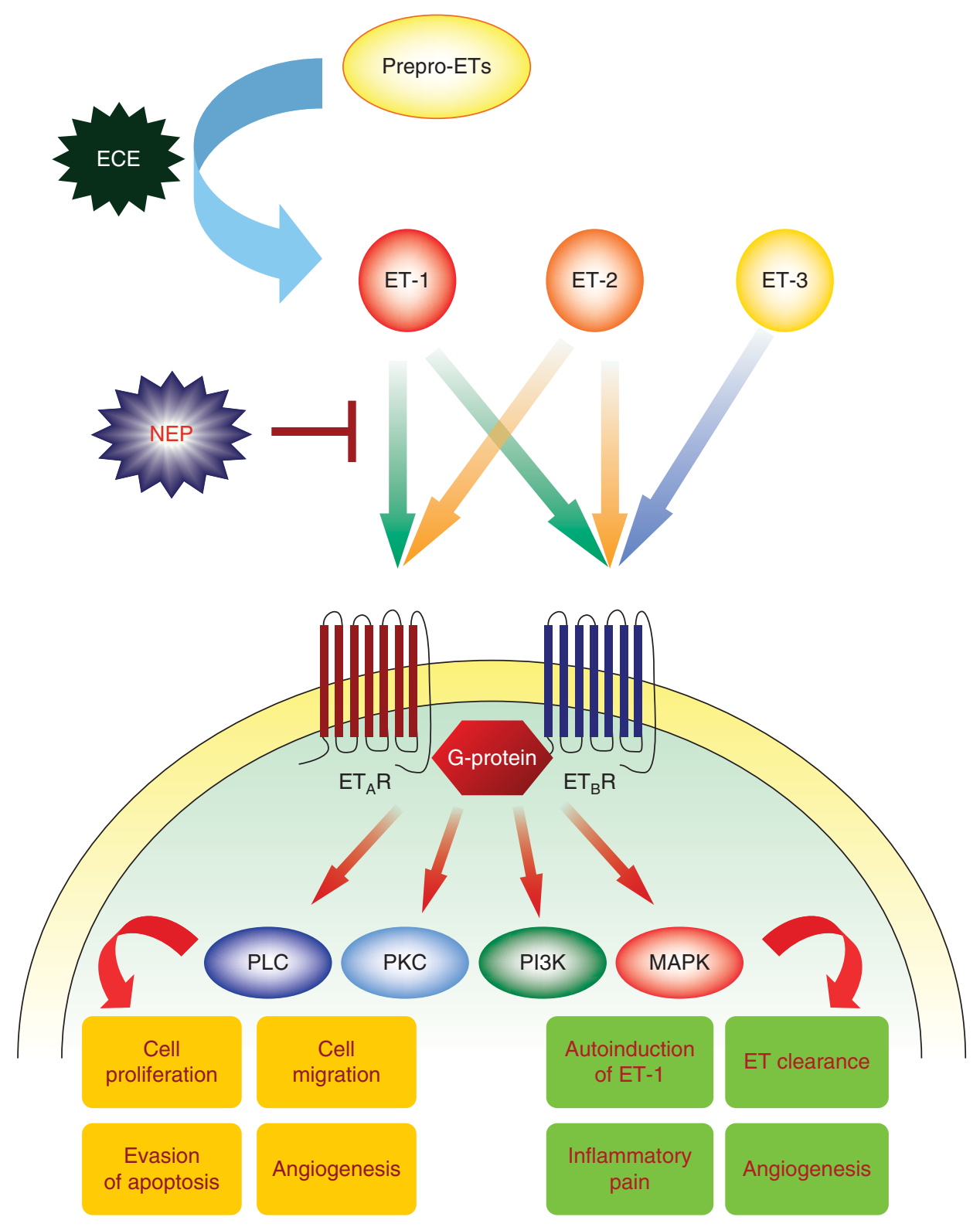

Figure 1. Molecular mechanisms of endothelin axis.

element binding site [3]. Furthermore, not only does ET-1 stabilize HIF-1 $\alpha$ under hypoxic and normoxic conditions, inducing the transcription of angiogenic genes, but HIF- $1 \alpha$ is also able to modulate transcription of ET-1 in various cell types. Moreover, the $\mathrm{ET}_{\mathrm{A}} \mathrm{R}$ blockade exerts an antiangiogenic effect by completely inhibiting growth and neoangiogenesis in different tumors [30].

Prostaglandins (PG) and their rate-limiting enzymes COX-1 and -2 are involved in the progression of a variety of malignancies in association with elevated levels of proangiogenic factors [31-33].

Under normoxic condition, ET-1 significantly stimulates the expression of COX-1 and -2 at mRNA and protein levels,
COX-2 promoter activity and prostaglandin $\mathrm{PGE}_{2}$ production. $\mathrm{PGE}_{2}$ promotes angiogenesis and this effect is mediated by VEGF. The use of EP agonists and antagonists indicates that ET-1 and $\mathrm{PGE}_{2}$ stimulate VEGF production, principally via two receptors, EP2 and EP4.

\subsection{Role of ET-1 in apoptosis}

Apoptosis is an active cell death process that takes place in a wide spectrum of physiologic situations such as normal cell turnover, embryogenesis and endocrine-dependent tissue atrophy.

Recently, investigations into the role of the ET axis in apoptosis inhibition have provided evidence of the importance 
of the ET-1 axis in cell survival. Previous studies have indicated a potential function for ET-1 in cell proliferation or as a cell survival factor.

Interaction between the Fas receptor (CD95/APO-1), a member of the TNF-receptor superfamily, and the Fas ligand (FasL) triggers a pathway to cell death involving caspase-8 activity. However, despite expression of Fas and caspase, death signals are frequently interrupted by also anti-apoptotic modulators, including caspase inhibitory proteins such as FLIP [34]. In human glioblastoma cell lines, ET-1, acting as survival factor, probably acts through ERK phosphorylation and the PKC pathway, determining a stabilization of the short form of FLIP protein [35]. The binding of ET-1 to high-affinity sites inhibits FasL-induced apoptosis, while the binding of either ET-1 or receptor antagonists to low-affinity sites promotes FasL-induced apoptosis. Thus, ET signaling pathways do not induce human cancer cell proliferation, but are survival signals controlling resistance to apoptosis [36].

As these effects are mediated by $\mathrm{ET}_{\mathrm{A}} \mathrm{R}$, activation of $\mathrm{ET}_{\mathrm{B}}$ by ET-1 conversely induces cell death via apoptosis in human cancer cells [37].

In ovarian carcinoma cells, the addition of ET-1 significantly inhibits paclitaxel-induced apoptosis in a dosedependent fashion as a result of $\mathrm{Bcl}-2$ phosphorylation suppression. ET-1 also stimulates Akt activation in a PI3K-dependent manner. Interestingly, the use of specific $\mathrm{ET}_{\mathrm{A}} \mathrm{R}$ antagonists has demonstrated that ET-1 contributes to paclitaxel resistance through $\mathrm{ET}_{\mathrm{A}} \mathrm{R}$ binding via activation of anti-apoptotic signaling pathways [21].

\subsection{Role of ET-1 in tumor invasiveness}

Tumor invasion is characterized by changes in MMPs, connexin, integrin and cadherin expression. The presence of high levels of ET-1 in ascitic fluids of ovarian cancer patients has shown that ET-1 may increase the secretion of extracellular matrix-degrading proteinases and metastatization process. In fact, $\mathrm{ET}_{\mathrm{A}} \mathrm{R}$ activation induces matrix-degrading enzymes, such as MMPs and urokinase plasminogen activator, which play important roles in tissue remodeling and tumor metastasis [38]. The ET-1 system acts by enhancing the invasive potential of tumor cells. ET-1, in fact, activates MMP-2, MMP-3, MMP-7, MMP-9 and MMP-13. EP2 and EP4 receptor antagonists block MMP activity and cell invasion, demonstrating that these receptors are the principal $\mathrm{PGE}_{2}$ receptors involved in these processes [39]. Furthermore, ET-1 stimulates focal adhesion kinase (FAK) and paxillin phosphorylation through the $\mathrm{ET}_{\mathrm{A}} \mathrm{R}$, which directly correlates with tumor cell migration and invasion [24]. This indicates that $\mathrm{ET}_{\mathrm{A}} \mathrm{R}$ antagonists can inhibit cell migration and possibly other FAK-associated processes.

Defects in regulation of intercellular communication, such as dysregulated or reduced expression of connexins, allow cancer cells to escape microenvironmental control from the normal surrounding tissue. ET-1 is able to disrupt gap junctions and this might serve as a basis to further evaluate the cell-cell metabolic uncoupling and the cell detachment that occurs during tumor progression [40]. In epithelial cancer, the loss of the epithelial features and the gain of a mesenchymal phenotype, a process known as epithelial to mesenchymal transition (EMT), determine the acquisition of tumor invasiveness. A primary event regulating EMT is the disruption of the E-cadherin-mediated stable interactions between the cells. In ovarian carcinoma cells, activation of the $\mathrm{ET}_{\mathrm{A}} \mathrm{R}$ pathway by ET-1 contributes to disruption of normal host-tumor interactions by downregulating the expression of E-cadherin and associated $\beta$-catenin adhesion proteins [41]. ET-1 induces expression of the transcription factor Snail, which has been identified as a potent repressor of E-cadherin expression.

\subsection{Role of ET-1 in osteogenesis}

The ET axis seems to have a central role in osteoblastic bone metastasis. Alkaline phosphatase, a marker of new bone formation, is elevated in the presence of exogenous ET-1 [42].

$\mathrm{ET}_{\mathrm{A}}$ and $\mathrm{ET}_{\mathrm{B}}$ appear to regulate tumor progression by a mechanism involving bone deposition in skeletal metastases through the activation of osteoblasts. It is thought that ET-1 production by metastatic cancer cells located in the bone is stimulated by osteoblast- and endothelial cell-secreted IL-1, TNF- $\alpha$ and TGF-h. ET-1, in turn, would stimulate mitotic activity in osteoblasts, decreasing both osteoclastic bone resorption and osteoclast motility [43,44]. Several experiments conducted in human prostate cancer cell lines have shown that osteoclastic bone resorption is significantly blocked by the presence of ET-1 in a dose-dependent fashion. In prostate and breast cancer models, selective $\mathrm{ET}_{\mathrm{A}} \mathrm{R}$ inhibition, but not $\mathrm{ET}_{\mathrm{B}} \mathrm{R}$ modulation, suppressed ET-1-induced osteoblastic response $[45,46]$. It seems that a calcineurin/FAT (nuclear factor of activated $\mathrm{T}$ cells) pathway is involved in the molecular mechanism of ET-1-mediated osteoblast stimulation.

\subsection{ET receptor antagonists' preclinical development}

ET-1 has shown pleiotropic mechanisms in different pathways of cancer development and progression. For this reason, many researchers have hypothesized a role of the ET-1 axis targeting for cancer treatment. Various approaches have been identified in order to impair ET biological function in tumors, for example, inhibition of ET biosynthesis, blockade of ET production from preproETs, promotion of ET degradation, selective blockade of $\mathrm{ET}_{\mathrm{A}} \mathrm{R} / \mathrm{ET}_{\mathrm{B}} \mathrm{R}$ activation and enhancement of tumor perfusion by $\mathrm{ET}_{\mathrm{B}} \mathrm{R}$ activation to potentiate efficacy of antineoplastic drugs.

Red wine polyphenols (i.e., quercetin, resveratrol, cathechins, etc.) can suppress ET-1 release and the transcription of prepro-ET-1 gene [47]. Similarly, green tea polyphenol epigallocatechin-3-gallate in ovarian carcinoma cells and xenografts have inhibited both $\mathrm{ET}_{\mathrm{A}} \mathrm{R}$ and ET-1 expression and reduced basal and ET-1-induced cell proliferation and invasion [48]. ET synthesis might be blocked by inhibition 
of the enzyme which converts preproETs into ETs. ECE inhibitors have been studied for various cardiovascular, renal, pulmonary and neurological diseases. They may be selective or may also inhibit the ACE and neutral endopeptidase [49]. ET degradation has been achieved by means of neutral endopeptidase transfection in ovarian carcinoma cells. NEP is a cell surface aminopeptidase with a ubiquitous expression and is able to degrade various bioactive peptides, including ET-1 [50].

Among all these options, the ET receptor blockade has reached the most advanced phases of preclinical and clinical drug development. Several small molecules functioning as $\mathrm{ET}_{\mathrm{A}} \mathrm{R}$ antagonists have provided a clearer understanding of the physiologic role of ET-1 and its effects on ET receptormediated signal transduction in tumor development and progression. Atrasentan and ZD-4054 are the most potent and selective $\mathrm{ET}_{\mathrm{A}} \mathrm{R}$ antagonists. They are orally bioavailable. For this reason, they are well qualified for clinical development in cancer treatment.

Atrasentan is able to inhibit effectively cell proliferation and VEGF secretion both in ovarian carcinoma cell lines and primary cultures. This action of atrasentan can be translated into biological effects such as reduction of microvessel density, VEGF and MMP-2 expression and increase in the percentage of apoptotic tumor cells.

Its combination with paclitaxel seems to be synergistic because of the enhancement of antitumor, proapoptotic and antiangiogenic effects. These phenomena may be explained by the sensitization to paclitaxel-induced apoptosis by the $\mathrm{ET}_{\mathrm{A}} \mathrm{R}$ blockade [51]. Moreover, the synergistic action of chemotherapy and $\mathrm{ET}_{\mathrm{A}} \mathrm{R}$ antagonists is supported by the finding of specific higher expression of $\mathrm{ET}_{\mathrm{A}} \mathrm{R}$ gene in postchemotherapy samples of primary ovarian tumors [52]. In breast carcinoma, the overexpression of $\mathrm{ET}_{\mathrm{A}} \mathrm{R}$ has induced resistance to chemotherapy. Some authors have suggested the use of the evaluation of $\mathrm{ET}_{\mathrm{A}} \mathrm{R}$ expression levels to predict the responsiveness of cancer patients to chemotherapy [53].

Atrasentan has induced tumor growth inhibition in xenografts of cervical carcinoma cells. This effect has been observed with just two cycles of treatment [54]. The additive effects of paclitaxel when combined with atrasentan have been obtained both in cervical carcinoma models [30] and in $\mathrm{ET}_{\mathrm{A}} \mathrm{R}$ overexpressing prostate cancer cells [43]. They are associated with a lower cell viability and a higher apoptotic rate.

In prostate cancer, the proliferative action of exogenous ET-1 is blocked by $\mathrm{ET}_{\mathrm{A}} \mathrm{R}$ antagonists. This observation has been explained by the finding of bone-tumor interaction impairment through the direct inhibition of osteoblasts. The role of ET receptor antagonists in prostate cancer is also supported by the finding of a high expression of $\mathrm{ET}_{\mathrm{A}} \mathrm{R}$, both in primary and metastatic tumors, which is associated with advanced tumor stage and grade.

$\mathrm{ET}_{\mathrm{A}} \mathrm{R}$ expression is also correlated with survival and might predict distant metastases in nasopharyngeal carcinoma (NPC) [55]. The inhibition of NPC cell proliferation by atrasentan depends on $\mathrm{ET}_{\mathrm{A}} \mathrm{R}$ expression. In this type of tumor, atrasentan has also induced more evident apoptotic effects when combined with cytotoxic drugs such as cisplatin and 5-fluorouracil in xenograft models. The xenografts of metastatic tumors have demonstrated a role for atrasentan in reducing metastases to the lung from both nasopharyngeal and bladder cancers [56,57].

Several other ET receptor antagonists have also been studied in preclinical cancer models.

Zibotentan (ZD-4054) is an orally active specific $\mathrm{ET}_{\mathrm{A}} \mathrm{R}$ antagonist. $\mathrm{ET}_{\mathrm{A}} \mathrm{R}$ blockade by zibotentan inhibits ET-1induced mitogenic effects, while the $\mathrm{ET}_{\mathrm{B}} \mathrm{R}$ antagonist, $\mathrm{BQ}$ 788 , is ineffective. Zibotentan is able to inhibit the proliferative activity of ET-1 in ovarian carcinoma cells [58]. The combination of zibotentan and paclitaxel produces additive effects on the reduction of $\mathrm{ET}_{\mathrm{A}} \mathrm{R}$-driven angiogenesis and invasive mediators, such as VEGF, COX-1/2 and MMP. Forty percent of mice bearing human ovarian cancer remained tumor-free, suggesting a possible clinical role of zibotentan as monotherapy or in combination with cytotoxic drugs [59]. In ovarian carcinoma xenografts, zibotentan has enhanced the efficacy of gefitinib, achieving partial (82\%) or complete tumor regression. A cross-talk between the EGFR and $\mathrm{ET}_{\mathrm{A}} \mathrm{R}$ pathways has been documented together with the evidence of decreased vascularization, Ki-67, MMP-2, VEGF, MAPK and EGFR, and enhanced E-cadherin expression [60].

Bosentan, a dual ET receptor antagonist targeting $\mathrm{ET}_{\mathrm{A}} \mathrm{R}$ and $\mathrm{ET}_{\mathrm{B}} \mathrm{R}$, has therapeutic indications for cardiovascular diseases. In a breast carcinoma cell metastasis model, bosentan has shown inhibition of tumor growth, neovascularization and bone metastasis. In melanoma xenografts, bosentan has enhanced the effects of alkylating agents, such as dacarbazine, when a combination treatment was delivered [61].

A-182086 is another dual antagonist. It can inhibit tumor growth by blocking proliferation not only of tumor cells but also of endothelial cells expressing $\mathrm{ET}_{\mathrm{B}} \mathrm{R}$. It has shown a potential role in Kaposi sarcoma treatment because of simultaneous interference with cell proliferation, invasiveness and angiogenesis $[62,63]$.

BQ788 is a peptide $\mathrm{ET}_{\mathrm{B}} \mathrm{R}$ antagonist which inhibits growth and induced death of melanoma cells in vitro and in vivo [64].

A-192621 is a specific $\mathrm{ET}_{\mathrm{B}} \mathrm{R}$ antagonist studied in xenografts of human melanoma cells. It suppresses HIF-1 $\alpha$ accumulation, tumor growth, neovascularization and VEGF and MMP-2 expression [65].

\section{Competitive environment}

The pharmaceutical development of ET receptor antagonists has derived from the observation of the prominent role of the ET-1 axis in cardiovascular diseases. ABT-627 is an agent developed by Abbott Laboratories; it is also known as atrasentan and marketed under the brand name of Xinlay. It is one of the most potent and selective $\mathrm{ET}_{\mathrm{A}} \mathrm{R}$ antagonists. Its 
effects on the ET-1 blockade were discovered in in vitro and in vivo models for cardiovascular diseases and malignancies. Atrasentan seems qualified for clinical use because it is orally bioavailable and has a half-life of $25 \mathrm{~h}$, thus, allowing daily delivery. It has produced mild adverse effects in healthy volunteers [66], for example, transient headache, rhinitis and nausea, which appear to be associated with atrasentan action on the inhibition of the function of ET-1 as a vasoconstrictor. However, no liver or hematological toxicity has been reported.

Atrasentan is able to increase plasma levels of ET-1 due to the blockade of $\mathrm{ET}_{\mathrm{B}}$. Zibotentan is the only ET receptor antagonist in clinical development that targets $\mathrm{ET}_{\mathrm{A}} \mathrm{R}$ without inhibition of $\mathrm{ET}_{\mathrm{B}} \mathrm{R}$ at doses under clinical investigation [67]. Table 1 reports a description of the main features of the agents of this class studied for anticancer treatment.

Prostate cancer patients have been identified as the best clinical setting for testing the safety and efficacy of ET receptor antagonists. Preclinical findings, in fact, have already shown a clear role of ET-1 in the development and progression of prostate carcinoma.

\subsection{Atrasentan}

Two Phase I clinical trials were designed to treat hormone refractory prostate cancer patients with escalating doses of atrasentan ranging between 2.5 and $95 \mathrm{mg}$ orally for 28 days. In one of the two studies, headache was found to be the doselimiting toxicity obtained at $75 \mathrm{mg}$, while in the other study the maximum tolerated dose was not reached. As previously found in healthy subjects, headache, rhinitis and peripheral edema were the most common side effects $[68,69]$. Even though prostate specific antigen (PSA) response was not the aim of the study, $68 \%(15 / 22)$ of patients achieved a reduction of PSA levels ranging between 5 and 95\%. Doses of atrasentan showed no correlation with PSA declines.

Ten patients in the same study were affected by pain which needed treatment with opioids. In all, $70 \%$ of them experienced pain reduction evaluated by VAS. Preclinical findings indicated the particular effect of ET-1 in inducing hyperalgesia and pain through cutaneous injection [70,71]. This phenomenon is mediated by the excitation of $\mathrm{ET}_{\mathrm{A}} \mathrm{R}$-mediated nociceptors. On the other hand, $\mathrm{ET}_{\mathrm{B}} \mathrm{R}$ activation induces analgesia by the release of $\beta$-endorphin and the activation of the opioid pool [72].

These effects of atrasentan in controlling cancer pain were studied in one Phase II clinical trial, double-blind and placebo-controlled; for hormone-refractory metastatic prostate cancer, patients were affected by pain needing opioid supplementation. The primary end point of this particular study was to evaluate the rate of pain relief after 12 weeks of treatment. No statistically significant difference was observed. A trend toward cancer pain amelioration with control of analgesic consumption was obtained only in the group of patients treated with $10 \mathrm{mg}$ atrasentan. In the same group, a statistical significance was observed in the improvement of 'pain interference with relations with other people' $(p=0.031)$ and 'worst pain in the last 24 h' $(p=0.030)$. This finding suggests a possible specific role of atrasentan to increase the quality of life [73].

A subsequent Phase II trial investigated the antitumor activity as identified through PSA reductions observed in previous Phase I studies. This second trial, double-blind and placebo-controlled, evaluated the effect on time-toprogression prolongation. Asymptomatic hormone-refractory metastatic prostate cancer patients were divided into three arms, those treated with a placebo, with $2.5 \mathrm{mg}$ and with $10 \mathrm{mg}$ atrasentan. In the evaluable set, but not in the intent-to-treat analysis, a statistically significant difference in the delay of disease progression was seen between placebo and $10 \mathrm{mg}$ atrasentan groups $(\mathrm{p}=0.021)$.

Overall survival analysis in this study found no significant advantage in the atrasentan arms versus placebo. This result seems to be due to the confounding effect of the crossover toward atrasentan treatment administered to placebo group patients. Survival advantage proved to be significant when atrasentan treatment groups were combined into a single arm achieving $\mathrm{HR}=0.69$ [68].

Tolerabilty profile included mild toxicity with headache, rhinitis and edema as the most common side effects.

The markers of bone deposition (alkaline phosphatase, bone alkaline phosphatase) and bone resorption (N-telopeptides, C-telopeptides and deoxypyridinoline) were evaluated in the same Phase II trial with atrasentan, which showed a dose-dependent effect on the stabilization of these markers and a clear trend toward the improvement of the bone scan index was found in the $10 \mathrm{mg}$ arm [74]. These findings agree with preclinical data regarding the role of the ET-1 axis in bone formation. Osteoblasts have shown the expression of high affinity $\mathrm{ET}_{\mathrm{A}} \mathrm{R}$ receptors and strong response to ET-1 stimulation leading to the osteoblastic proliferation associated with metastatic breast and prostate cancers [44,75]. In vivo models of bone metastasis have clarified the role of $\mathrm{ET}_{\mathrm{A}} \mathrm{R}$ in osteogenesis by means of the use of $\mathrm{ET}_{\mathrm{A}} \mathrm{R}$ antagonists [46].

On the basis of the clinical findings of a Phase II trial involving disease progression delay, a Phase III clinical study (M00-211) was designed to verify the ability of atrasentan to duplicate time to progression in asymptomatic hormonerefractory metastatic prostate cancer patients. These were grouped into two arms, placebo and $10 \mathrm{mg}$ atrasentan. Secondary end points were PSA response rate, markers of bone metabolism and quality of life. As in the Phase II M96-594 trial, time to progression was significantly delayed in the evaluable set analysis but not in the intent-to-treat analysis ( $\mathrm{p}=0.007$ vs 0.091 ). All the secondary end points showed a significant favor trend for the $10 \mathrm{mg}$ atrasentan arm. Moreover, in the $10 \mathrm{mg}$ atrasentan group, a stratification of this trial data made it possible to observe a significant 
Table 1. Endothelin receptor antagonists studied in clinical trials for cancer treatment.

\begin{tabular}{|c|c|c|c|c|c|}
\hline Compound & Company & Mechanism of action & Indication & $\begin{array}{l}\text { Stage of } \\
\text { development }\end{array}$ & Side effects \\
\hline $\begin{array}{l}\text { Atrasentan } \\
\text { (ABT-627, } \\
\text { Xinlay) }\end{array}$ & Abbott, USA & $\begin{array}{l}E T_{A} R \text { antagonist } \\
\text { Reduction of microvessel density, } \\
\text { VEGF and } \\
\text { MMP-2 expression and increase } \\
\text { of the percentage of apoptotic } \\
\text { tumor cells }\end{array}$ & $\begin{array}{l}\text { Castration-resistant } \\
\text { prostate cancer }\end{array}$ & Phase III trial & $\begin{array}{l}\text { Headache, } \\
\text { rhinitis and } \\
\text { nausea }\end{array}$ \\
\hline $\begin{array}{l}\text { Zibotentan } \\
\text { (ZD-4054) }\end{array}$ & AstraZeneca, UK & $\begin{array}{l}\mathrm{ET}_{\mathrm{A}} \mathrm{R} \text { antagonist } \\
\text { Inhibits } \mathrm{ET} \text {-1-induced mitogenic } \\
\text { effects } \\
\text { The combination with paclitaxel } \\
\text { produces additive effects on } \\
\text { the reduction of } \mathrm{ET}_{\mathrm{A}} \mathrm{R} \text {-driven } \\
\text { angiogenesis and invasive } \\
\text { mediators }\end{array}$ & $\begin{array}{l}\text { Castration-resistant } \\
\text { prostate cancer }\end{array}$ & Phase III trial & $\begin{array}{l}\text { Headache, } \\
\text { peripheral } \\
\text { edema, fatigue, } \\
\text { nasal congestion } \\
\text { and nausea }\end{array}$ \\
\hline Bosentan & $\begin{array}{l}\text { Hoffmann-La } \\
\text { Roche, } \\
\text { Switzerland }\end{array}$ & $\begin{array}{l}\text { Dual ET receptor antagonist } \\
\text { targeting } \\
\mathrm{ET}_{\mathrm{A}} \mathrm{R} \text { and } \mathrm{ET}_{\mathrm{B}} \mathrm{R} \\
\text { Inhibits tumor growth, } \\
\text { neovascularization and bone } \\
\text { metastasis }\end{array}$ & Melanoma & Phase II trial & $\begin{array}{l}\text { Headache, } \\
\text { fatigue, nausea, } \\
\text { back pain and } \\
\text { abnormal } \\
\text { hepatic function }\end{array}$ \\
\hline
\end{tabular}

ET: Endothelin; $\mathrm{ET}_{\mathrm{A}} \mathrm{R}$ : Endothelin $\mathrm{A}$ receptor; $\mathrm{ET}_{\mathrm{B}} \mathrm{R}$ : Endothelin $\mathrm{B}$ receptor.

prolongation of time to progression in the subgroup of patients with bone metastases independently of soft tissue metastases [76]. This finding suggests interesting implications regarding the clinical use of atrasentan in CRPC due to the large number of patients (85\%) with bone metastasis.

Subsequently, another Phase III trial was performed in nonmetastatic hormone-refractory prostate cancer patients with no radiographic evidence of metastases but rising PSA levels. These were randomized to receive $10 \mathrm{mg}$ atrasentan or placebo. The primary end point, time to progression defined as the time to the onset of metastases, was not achieved. A favoring trend for atrasentan was highlighted through the evaluation of the secondary end points: time to PSA progression, change in bone alkaline phosphatase levels, PSA doubling time and overall survival. Large geographic differences in the median time to progression were observed, which implies that trial conduct may have influenced the results. A more adequate study design should, therefore, be considered [77].

Atrasentan has also been studied in clinical trials involving the combination with other antineoplastic agents. A Phase II study for the comparison between atrasentan alone and its combination with zoledronic acid was designed to evaluate bone turnover markers in men with bone metastases from prostate cancer. There is no evidence for additive or synergistic effects of combination treatment on these markers [78].

Preclinical data regarding the combination therapy with taxanes and atrasentan have already suggested a potential role in the treatment of refractory malignancies. In metastatic CRPC patients, a Phase I/II trial investigated the feasibility of docetaxel at doses ranging from 60 to $75 \mathrm{mg} / \mathrm{m}^{2}$ every 21 days, with daily oral atrasentan $10 \mathrm{mg}$ starting on day 3 until evidence of disease progression or unacceptable toxicity. The maximum tolerated dose of docetaxel in this regimen is $70-75 \mathrm{mg} / \mathrm{m}^{2}$. Overall survival and progression-free survival are similar to that normally obtained with docetaxel and prednisone. The PSA response rates are slightly lower than expected. A Phase III trial to compare this combination with docetaxel and prednisone had already been designed and is still ongoing [79].

In advanced NSCLC, $10 \mathrm{mg} /$ day atrasentan plus standard paclitaxel-carboplatin combination have been investigated for safety and pharmacokinetics. They appear to be well tolerated, without pharmacokinetic interaction of paclitaxel and atrasentan. Efficacy and survival have proved to be similar to those already observed in studies involving the use of chemotherapy alone in advanced NSCLC patients [80]. Phase III trials and other combination regimen trials should also be designed.

\subsection{Zibotentan}

Zibotentan, when studied in asymptomatic or mildly symptomatic hormone-refractory prostate cancer patients with bone metastases, obtained similar results. Primary end point (time to progression) was not achieved, but advantage in overall survival was seen in both 10 and $15 \mathrm{mg}$ zibotentan arms [81].

A subsequent Phase I study evaluated escalating doses of zibotentan ranging between 10 and $200 \mathrm{mg} / \mathrm{day}$ p.o. in 
Russo, Bronte, Rizzo, Fanale, Di Gaudio, Gebbia \& Bazan

Table 2. Clinical studies with $\mathrm{ET}_{\mathrm{A}} \mathrm{R}$ antagonists.

\begin{tabular}{|c|c|c|c|c|c|}
\hline Citation & Phase & Patients & Agents & Schedule & Results \\
\hline \multicolumn{6}{|l|}{ Atrasentan } \\
\hline $\begin{array}{l}\text { Zonnenberg } \\
2003 \text { [69] }\end{array}$ & 1 & Metastatic CRPC & Atrasentan & $\begin{array}{l}\text { A } 2.5-95 \text { mg/day } \\
\text { p.o. }\end{array}$ & $\begin{array}{l}\text { No dose-limiting adverse } \\
\text { events observed up to } \\
95 \mathrm{mg} \\
\text { The most common adverse } \\
\text { events were rhinitis, } \\
\text { headache and peripheral } \\
\text { edema }\end{array}$ \\
\hline $\begin{array}{l}\text { Armstrong } \\
2008 \text { [79] }\end{array}$ & $|/| \mid$ & Metastatic CRPC & $\begin{array}{l}\text { Atrasentan } \\
+ \text { docetaxel }\end{array}$ & $\begin{array}{l}\text { A } 10 \mathrm{mg} / \text { day p.o. } \\
+ \text { D every } 3 \text { weeks } \\
\text { i.v. } 60-75 \mathrm{mg} / \mathrm{m}^{2}\end{array}$ & $\begin{array}{l}\text { Overall survival and } \\
\text { progression-free survival } \\
\text { are comparable to that } \\
\text { seen with docetaxel and } \\
\text { prednisone, whereas the } \\
\text { rates of PSA decline are } \\
\text { slightly lower than } \\
\text { expected } \\
\text { Drug-related grade } 3-4 \\
\text { toxicities included } \\
\text { neutropenia (50-63\%) } \\
\text { and febrile neutropenia } \\
\text { (16-25\%) }\end{array}$ \\
\hline $\begin{array}{l}\text { Chiappori } \\
2008[80]\end{array}$ & $|/| I$ & Advanced NSCLC & $\begin{array}{l}\text { Atrasentan }+ \\
\text { carboplatin }+ \\
\text { paclitaxel }\end{array}$ & $\begin{array}{l}\text { A } 10 \mathrm{mg} / \text { day p.o. } \\
+ \text { C every } 3 \text { weeks } \\
\text { i.v. AUC6 + P every } \\
3 \text { weeks i.v. } \\
225 \mathrm{mg} / \mathrm{m}^{2}\end{array}$ & $\begin{array}{l}\text { Atrasentan plus } \\
\text { paclitaxel-carboplatin was } \\
\text { safe and well tolerated, } \\
\text { with no apparent } \\
\text { paclitaxel-atrasentan } \\
\text { pharmacokinetic } \\
\text { interaction } \\
\text { Efficacy and survival in } \\
\text { advanced NSCLC were } \\
\text { comparable with studies of } \\
\text { chemotherapy alone }\end{array}$ \\
\hline $\begin{array}{l}\text { Carducci } \\
2003[68]\end{array}$ & $\|$ & Metastatic CRPC & $\begin{array}{l}\text { Atrasentan } \\
\text { vs placebo }\end{array}$ & $\begin{array}{l}\text { A } 2.5 \text { mg/day p.o. } \\
\text { A } 10 \text { mg/day p.o. } \\
\text { Placebo }\end{array}$ & $\begin{array}{l}\text { Median TTP prolongation } \\
\text { Headache, peripheral } \\
\text { edema and rhinitis were } \\
\text { primary side effects }\end{array}$ \\
\hline $\begin{array}{l}\text { Michaelson } \\
2006[78]\end{array}$ & $\|$ & $\begin{array}{l}\text { Prostate cancer } \\
\text { with bone } \\
\text { metastases }\end{array}$ & $\begin{array}{l}\text { Atrasentan }+ \\
\text { zoledronic acid }\end{array}$ & $\begin{array}{l}\text { A } 10 \text { mg/day p.o. } \\
\text { A } 10 \text { mg/day p.o. + } \\
\text { ZA every } 4 \text { weeks } \\
\text { i.v. }\end{array}$ & $\begin{array}{l}\text { No evidence for additive or } \\
\text { synergistic effects of } \\
\text { combination therapy with } \\
\text { atrasentan and zoledronic } \\
\text { acid on bone turnover } \\
\text { markers } \\
\text { Commonly observed } \\
\text { adverse effects were } \\
\text { edema, rhinitis, fatigue } \\
\text { and shortness of breath }\end{array}$ \\
\hline $\begin{array}{l}\text { Carducci } \\
2007[76]\end{array}$ & III & Metastatic CRPC & $\begin{array}{l}\text { Atrasentan vs } \\
\text { placebo }\end{array}$ & $\begin{array}{l}\text { A } 10 \text { mg/day p.o. } \\
\text { Placebo }\end{array}$ & $\begin{array}{l}\text { Atrasentan did not delay } \\
\text { disease progression in men } \\
\text { with metastatic CRPC } \\
\text { despite evidence of } \\
\text { biologic effects on markers } \\
\text { of disease burden }\end{array}$ \\
\hline
\end{tabular}

A: Atrasentan; B: Bosentan; b.i.d.: Twice a day; C: Carboplatin; CRPC: Castration-resistant prostate cancer; D: Docetaxel; ET $\mathrm{A}$ : Endothelin A receptor; i.v.: Intravenous; MWTD: Maximum well-tolerated dose; P: Paclitaxel; p.o.: Per oS; PSA: Prostate specific antigen ; TTP: Time to progression; Z: Zibotentan; ZA: Zoledronic acid. 
Table 2. Clinical studies with $\mathrm{ET}_{\mathrm{A}} \mathrm{R}$ antagonists (continued).

\begin{tabular}{|c|c|c|c|c|c|}
\hline Citation & Phase & Patients & Agents & Schedule & Results \\
\hline $\begin{array}{l}\text { Nelson } \\
2008 \text { [77] }\end{array}$ & III & Nonmetastatic CRPC & $\begin{array}{l}\text { Atrasentan vs } \\
\text { placebo }\end{array}$ & $\begin{array}{l}\text { A } 10 \text { mg/day p.o. } \\
\text { Placebo }\end{array}$ & $\begin{array}{l}\text { Although the primary end } \\
\text { point was not achieved, } \\
\text { large regional differences } \\
\text { in TTP were noted, } \\
\text { suggesting that trial } \\
\text { conduct may have } \\
\text { influenced the results }\end{array}$ \\
\hline
\end{tabular}

\section{Zibotentan}

James

2009 [81]

II

Bosentan

Kefford

2007 [83]

।
Metastatic CRPC

Metastatic CRPC

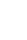

Metastatic
melanoma
Zibotentan vs placebo

Zibotentan Z 10 mg/day p.o.
Z 15 mg/day p.o.
Placebo

Z $10-200 \mathrm{mg} /$ day p.o.

Bosentan
B $500 \mathrm{mg} /$ day p.o.

\begin{abstract}
The primary end point of TTP was not achieved in this study, but an improvement was seen in overall survival in both active treatment arms Adverse events were in line with the expected pharmacologic effects of an $\mathrm{ET}_{\mathrm{A}} \mathrm{R}$ antagonist

The MWTD for zibotentan was $15 \mathrm{mg}$ Dose-limiting toxicity was similar to that reported for other drugs of this class Some patients experienced prolonged stable disease

Benefit in disease stabilization The most frequent adverse events were headache, fatigue, nausea, back pain and abnormal hepatic function
\end{abstract}

\begin{abstract}
A: Atrasentan; B: Bosentan; b.i.d.: Twice a day; C: Carboplatin; CRPC: Castration-resistant prostate cancer; D: Docetaxel; ETAR: Endothelin A receptor; i.v.: Intravenous; MWTD: Maximum well-tolerated dose; P: Paclitaxel; p.o.: Per os; PSA: Prostate specific antigen ; TTP: Time to progression; Z: Zibotentan; ZA: Zoledronic acid.
\end{abstract}

metastatic CRPC patients. The maximum well-tolerated dose for zibotentan was $15 \mathrm{mg} /$ day p.o. Dose-limiting toxicity was similar to that reported for other drugs of this class. Some patients experienced prolonged stable disease, suggesting that new methods are needed to test antitumor activity [82].

Phase III studies with zibotentan in the same setting of patients are ongoing.

\subsection{Bosentan}

Bosentan, the dual $\mathrm{ET}_{\mathrm{A}} \mathrm{R} / \mathrm{ET}_{\mathrm{B}} \mathrm{R}$ antagonist, was also studied in a Phase II trial with metastatic melanoma patients. No tumor responses were obtained, but disease stabilization was found in about $20 \%$ of patients suggesting the need for further investigation in combination with other anticancer drugs [83]. Table 2 summarizes all the clinical trials with ET receptor antagonists studied for cancer treatment.

\section{Conclusions}

ETs belong to a family of proteins with regulatory activity in different cellular pathways, including cell growth, survival, invasion and angiogenesis. ET-1, which mainly exert their function on the $\mathrm{ET}_{\mathrm{A}} \mathrm{R}$, has shown a role in the various phases of carcinogenesis and cancer progression of different tumor types. Preclinical studies have demonstrated the capability of ET antagonists in inhibiting tumor cell proliferation, invasiveness and new vessel formation, as well as their effects on osteogenesis and cancer-related pain. The clinical investigation of an orally bioavailable ET antagonist, atrasentan, has suggested its benefit in PSA progression, markers of bone turnover, and pain in men with prostate cancer, but improvement in time to progression and overall survival has not yet been demonstrated with sufficient statistical significance, perhaps because of the small number of patients included in 
the clinical trials. This class of drugs seems quite promising, above all for CRPC patients. Nevertheless, we should define their exact role in different cancer treatments by means of future clinical trials.

\section{Expert opinion}

The ET axis, which includes the biological functions of the ETs and their receptors, has played a physiological role in normal tissue, acting as a modulator of vasomotor tone, tissue differentiation and development, cell proliferation and hormone production. Interestingly, it also functions in the growth and progression of various tumors. In vitro and in vivo studies have suggested that it can trigger signaling pathways implicated in various hallmarks of cancer, including aberrant cell proliferation, adhesion, migration, invasion, angiogenesis and antiapoptotic activity.

Several researchers have identified the blockade of the ET-1 receptor as a promising therapeutic approach.

Preclinical findings have highlighted the fact that ET-1 receptor antagonists enhance the efficacy of cytotoxic drugs. When $\mathrm{ET}_{\mathrm{A}} \mathrm{R}$ is blocked by its antagonists, the cancer cells are sensitized to the apoptotic potential of chemotherapeutics drugs. The finding of sensitization to paclitaxel is an example of this phenomenon obtained by ovarian and cervical carcinoma preclinical models.

Atrasentan - one of the most potent and selective $\mathrm{ET}_{\mathrm{A}} \mathrm{R}$ antagonists - has been the most effectively studied, because it has been included in two Phase III clinical trials as monotherapy and Phase I/II combination trials with chemotherapy. It has shown a quite amazing tolerability profile and even the means of administration - oral - would allow a wide applicability if its preliminary efficacy results are subsequently confirmed. Time to progression, which is the primary end point of the Phase III trials with atrasentan, has been achieved only in the evaluable set of metastatic patients. No statistically significant efficacy has been observed in the intent-to-treat analysis. Overall survival, one of the secondary end points, has confirmed a non-positive trend in favor of patients treated with atrasentan independently of its dose. All these results suggest that more effective clinical trials are required in order to evaluate $\mathrm{ET}_{\mathrm{A}} \mathrm{R}$ antagonists.

To date, the treatment of prostate cancer patients is the only clinical setting to be extensively studied for therapy with atrasentan. Unsatisfactory results have been obtained from a Phase II trial with bosentan in metastatic melanoma patients.

The improved characterization of the ET-1 axis will provide a valid target for more promising molecular treatment strategies to combine with known anticancer drugs. The synergistic action of ZD-4054 and gefitinib on tumor burden reduction is the best demonstration of this therapeutic potential.

The choice of the most adequate end point to define the clinical efficacy of these drugs remains the most controversial feature. Statistical power, baseline characteristics of patients and pharmaceutical doses are the parameters to emphasize in order to reach a definite understanding of the role of these new agents in cancer treatment.

Combination clinical trials with chemotherapy or other anticancer agents in various malignancies are needed. These studies will found a proper rationale in the results of the combination Phase I/II trials with atrasentan and standard chemotherapeutic drugs in prostate and lung cancers.

Nevertheless, different end points, not only clinical but also molecular, should be identified in order to reach a better understanding of the most appropriate application of these agents in the treatment of solid tumors.

\section{Acknowledgements}

A Russo and G Bronte have contributed equally to this work.

\section{Declaration of interest}

The authors state no conflict of interest and have received no payment in preparation of this manuscript. 


\section{Bibliography}

1. Yanagisawa M, Inoue A, Ishikawa T, et al. Primary structure, synthesis, and biological activity of rat endothelin, an endothelium-derived vasoconstrictor peptide. Proc Natl Acad Sci USA 1988;85(18):6964-7

2. Masaki T. Historical review: endothelin. Trends Pharmacol Sci 2004;25(4):219-24

3. Bagnato A, Natali PG. Endothelin receptors as novel targets in tumor therapy. J Transl Med 2004;2(1):16

-4. Levin ER. Endothelins. N Engl J Med 1995;333(6):356-63

5. Masaki T. The endothelin family: an overview. J Cardiovasc Pharmacol 2000;35(4 Suppl 2):S3-5

6. Schweizer A, Valdenaire O, Nelbock P, et al. Human endothelin-converting enzyme (ECE-1): three isoforms with distinct subcellular localizations. Biochem J 1997;328 (Pt 3):871-7

7. Xu D, Emoto N, Giaid A, et al. ECE-1: a membrane-bound metalloprotease that catalyzes the proteolytic activation of big endothelin-1. Cell 1994;78(3):473-85

8. Rubin SA, Levin ER. Clinical review 53: The endocrinology of vasoactive peptides: synthesis to function. J Clin Endocrinol Metab 1994;78(1):6-10

9. Clozel M, Fischli W, Guilly C. Specific binding of endothelin on human vascular smooth muscle cells in culture.

J Clin Invest 1989;83(5):1758-61

10. Clozel M, Gray GA, Breu V, et al. The endothelin ETB receptor mediates both vasodilation and vasoconstriction in vivo. Biochem Biophys Res Commun 1992;186(2):867-73

11. Haynes WG, Webb DJ. The endothelin family of peptides: local hormones with diverse roles in health and disease? Clin Sci (Lond) 1993;84(5):485-500

12. Foster N, Loi TH, Owe-Young R, Stanley KK. Lysosomal traffic of liganded endothelin B receptor.

Biochim Biophys Acta 2003;1642(1-2):45-52

13. Bkaily G, Nader M, Avedanian L, et al. G-protein-coupled receptors, channels, and $\mathrm{Na}+-\mathrm{H}+$ exchanger in nuclear membranes of heart, hepatic, vascular endothelial, and smooth muscle cells. Can J Physiol Pharmacol 2006;84(3-4):431-41
14. Nelson J, Bagnato A, Battistini B, Nisen P. The endothelin axis: emerging role in cancer. Nat Rev Cancer 2003;3(2):110-6

15. Remuzzi G, Perico N, Benigni A. New therapeutics that antagonize endothelin: promises and frustrations. Nat Rev Drug Discov 2002;1(12):986-1001

16. Ali H, Dashwood M, Dawas K, et al. Endothelin receptor expression in colorectal cancer. J Cardiovasc Pharmacol 2000 36(5 Suppl 1):S69-71

17. Hirata Y. Endothelin-1 receptors in cultured vascular smooth muscle cells and cardiocytes of rats. J Cardiovasc Pharmacol 1989;13(Suppl 5):S157-8

18. Kusuhara M, Yamaguchi K, Ohnishi A, et al. Endothelin potentiates growth factor-stimulated DNA synthesis in Swiss 3T3 cells. Jpn J Cancer Res 1989;80(4):302-5

19. Shichiri M, Hirata Y, Marumo F. Endothelin-1 as an autocrine/paracrine factor for human tumor cell lines. J Cardiovasc Pharmacol 1991;17(Suppl 7):S76-8

20. Simonson MS, Wann S, Mene P, et al. Endothelin-1 activates the phosphoinositide cascade in cultured glomerular mesangial cells. J Cardiovasc Pharmacol 1989;13(Suppl 5):S80-3, discussion S4

21. Bagnato A, Spinella F, Rosano L. Emerging role of the endothelin axis in ovarian tumor progression. Endocr Relat Cancer 2005;12(4):761-72

22. Rauh A, Windischhofer W, Kovacevic A, et al. Endothelin (ET)-1 and ET-3 promote expression of c-fos and c-jun in human choriocarcinoma via $\mathrm{ET}(\mathrm{B})$ receptor-mediated $\mathrm{G}(\mathrm{i})$ - and $\mathrm{G}$ (q)-pathways and MAP kinase activation. Br J Pharmacol 2008;154(1):13-24

23. Bagnato A, Catt KJ. Endothelins as autocrine regulators of tumor cell growth. Trends Endocrinol Metab 1998;9(9):378-83

24. Bagnato A, Tecce R, Di Castro V, Catt KJ. Activation of mitogenic signaling by endothelin 1 in ovarian carcinoma cells. Cancer Res 1997;57(7):1306-11

25. Vacca F, Bagnato A, Catt KJ, Tecce R. Transactivation of the epidermal growth factor receptor in endothelin-1-induced mitogenic signaling in human ovarian carcinoma cells. Cancer Res 2000;60(18):5310-7
26. Eguchi S, Hirata $Y$, Imai $T$, et al. Phenotypic change of endothelin receptor subtype in cultured rat vascular smooth muscle cells. Endocrinology 1994;134(1):222-8

27. Battistini B, Chailler P, D’Orleans-Juste P, et al. Growth regulatory properties of endothelins. Peptides 1993;14(2):385-99

28. Carmeliet P, Jain RK. Angiogenesis in cancer and other diseases. Nature 2000;407(6801):249-57

29. Salani D, Taraboletti G, Rosano L, et al. Endothelin-1 induces an angiogenic phenotype in cultured endothelial cells and stimulates neovascularization in vivo. Am J Pathol 2000;157(5):1703-11

30. Bagnato A, Cirilli A, Salani D, et al. Growth inhibition of cervix carcinoma cells in vivo by endothelin A receptor blockade. Cancer Res 2002;62(22):6381-4

31. Dannenberg AJ, Subbaramaiah K. Targeting cyclooxygenase- 2 in human neoplasia: rationale and promise. Cancer Cell 2003;4(6):431-6

32. Denkert C, Kobel M, Pest $S$, et al. Expression of cyclooxygenase 2 is an independent prognostic factor in human ovarian carcinoma. Am J Pathol 2002;160(3):893-903

33. Ferrandina G, Lauriola L, Zannoni GF, et al. Increased cyclooxygenase-2 (COX-2) expression is associated with chemotherapy resistance and outcome in ovarian cancer patients. Ann Oncol 2002;13(8):1205-11

34. Irmler M, Thome M, Hahne M, et al. Inhibition of death receptor signals by cellular FLIP. Nature 1997;388(6638):190-5

35. Egidy G, Eberl LP, Valdenaire O, et al. The endothelin system in human glioblastoma. Lab Invest 2000;80(11):1681-9

36. Peduto Eberl L, Bovey R, Juillerat-Jeanneret L. Endothelin-receptor antagonists are proapoptotic and antiproliferative in human colon cancer cells. Br J Cancer 2003;88(5):788-95

37. Okazawa M, Shiraki T, Ninomiya H, et al. Endothelin-induced apoptosis of A375 human melanoma cells. J Biol Chem 1998;273(20):12584-92

38. Salani D, Di Castro V, Nicotra MR, et al. Role of endothelin-1 in neovascularization of ovarian carcinoma. Am J Pathol 2000;157(5):1537-47 
39. Spinella F, Rosano L, Di Castro V, et al. Endothelin-1-induced prostaglandin E2-EP2, EP4 signaling regulates vascular endothelial growth factor production and ovarian carcinoma cell invasion. J Biol Chem 2004;279(45):46700-5

40. Spinella F, Rosano L, Di Castro V, et al. Endothelin-1 decreases gap junctional intercellular communication by inducing phosphorylation of connexin 43 in human ovarian carcinoma cells. J Biol Chem 2003;278(42):41294-301

41. Rosano L, Spinella F, Di Castro V, et al. Endothelin-1 promotes epithelial-to-mesenchymal transition in human ovarian cancer cells. Cancer Res 2005;65(24):11649-57

42. Nelson JB, Hedican SP, George DJ, et al. Identification of endothelin-1 in the pathophysiology of metastatic adenocarcinoma of the prostate. Nat Med 1995;1(9):944-9

43. Carducci MA, Jimeno A. Targeting bone metastasis in prostate cancer with endothelin receptor antagonists. Clin Cancer Res 2006;12(20 Pt 2):6296s-300s

44. Nelson JB, Nguyen SH, Wu-Wong JR, et al. New bone formation in an osteoblastic tumor model is increased by endothelin-1 overexpression and decreased by endothelin A receptor blockade. Urology 1999;53(5):1063-9

45. Guise TA, Yin JJ, Mohammad KS. Role of endothelin-1 in osteoblastic bone metastases. Cancer 2003;97(Suppl 3):779-84

46. Yin JJ, Mohammad KS, Kakonen SM, et al. A causal role for endothelin-1 in the pathogenesis of osteoblastic bone metastases. Proc Natl Acad Sci USA 2003;100(19):10954-9

47. Corder R, Douthwaite JA, Lees DM, et al. Endothelin-1 synthesis reduced by red wine. Nature 2001;414(6866):863-4

48. Spinella F, Rosano L, Di Castro V, et al. Green tea polyphenol epigallocatechin-3-gallate inhibits the endothelin axis and downstream signaling pathways in ovarian carcinoma.

Mol Cancer Ther 2006;5(6):1483-92

49. Jeng AY, Mulder P, Kwan AL, Battistini B. Nonpeptidic endothelin-converting enzyme inhibitors and their potential therapeutic applications.

Can J Physiol Pharmacol 2002;80(5):440-9
50. Kajiyama H, Shibata K, Terauchi M, et al. Neutral endopeptidase 24.11/CD10 suppresses progressive potential in ovarian carcinoma in vitro and in vivo. Clin Cancer Res 2005;11(5):1798-808

51. Rosano L, Spinella F, Salani D, et al. Therapeutic targeting of the endothelin a receptor in human ovarian carcinoma. Cancer Res 2003;63(10):2447-53

52. Jazaeri AA, Awtrey CS, Chandramouli GV, et al. Gene expression profiles associated with response to chemotherapy in epithelial ovarian cancers. Clin Cancer Res 2005;11(17):6300-10

53. Smollich M, Wulfing $P$. The endothelin axis: a novel target for pharmacotherapy of female malignancies. Curr Vasc Pharmacol 2007:5(3):239-48

54. Venuti A, Salani D, Manni V, et al. Expression of endothelin 1 and endothelin A receptor in HPV-associated cervical carcinoma: new potential targets for anticancer therapy. FASEB J 2000;14(14):2277-83

55. Mai HQ, Zeng ZY, Zhang CQ, et al. Elevated plasma big ET-1 is associated with distant failure in patients with advanced-stage nasopharyngeal carcinoma. Cancer 2006;106(7):1548-53

56. Mai HQ, Zeng ZY, Feng KT, et al. Therapeutic targeting of the endothelin a receptor in human nasopharyngeal carcinoma. Cancer Sci 2006;97(12):1388-95

57. Titus B, Frierson HF Jr, Conaway M, et al. Endothelin axis is a target of the lung metastasis suppressor gene RhoGDI2. Cancer Res 2005;65(16):7320-7

58. Rosano L, Di Castro V, Spinella F, et al. ZD4054, a potent endothelin receptor A antagonist, inhibits ovarian carcinoma cell proliferation. Exp Biol Med (Maywood) 2006;231(6):1132-5

59. Rosano L, Di Castro V, Spinella F, et al. ZD4054, a specific antagonist of the endothelin A receptor, inhibits tumor growth and enhances paclitaxel activity in human ovarian carcinoma in vitro and in vivo. Mol Cancer Ther 2007;6(7):2003-11

60. Rosano L, Di Castro V, Spinella F, et al. Combined targeting of endothelin A receptor and epidermal growth factor receptor in ovarian cancer shows enhanced antitumor activity. Cancer Res 2007;67(13):6351-9
61. Berger Y, Bernasconi CC, Juillerat-Jeanneret L. Targeting the endothelin axis in human melanoma: combination of endothelin receptor antagonism and alkylating agents. Exp Biol Med (Maywood) 2006;231(6):1111-9

62. Bagnato A, Rosano L, Di Castro V, et al. Endothelin receptor blockade inhibits proliferation of Kaposi's sarcoma cells. Am J Pathol 2001;158(3):841-7

63. Rosano L, Spinella F, Di Castro V, et al. Endothelin receptor blockade inhibits molecular effectors of Kaposi's sarcoma cell invasion and tumor growth in vivo. Am J Pathol 2003;163(2):753-62

64. Lahav R, Heffner G, Patterson PH. An endothelin receptor $\mathrm{B}$ antagonist inhibits growth and induces cell death in human melanoma cells in vitro and in vivo. Proc Natl Acad Sci USA 1999;96(20):11496-500

65. Spinella F, Rosano L, Di Castro V, et al. Endothelin-1 and endothelin-3 promote invasive behavior via hypoxia-inducible factor-1alpha in human melanoma cells. Cancer Res 2007;67(4):1725-34

66. Samara E, Dutta $S$, Cao G, et al. Single-dose pharmacokinetics of atrasentan, an endothelin-A receptor antagonist. J Clin Pharmacol 2001;41(4):397-403

67. Morris CD, Rose A, Curwen J, et al. Specific inhibition of the endothelin A receptor with ZD4054: clinical and pre-clinical evidence. $\mathrm{Br} \mathrm{J}$ Cancer 2005;92(12):2148-52

68. Carducci MA, Padley RJ, Breul J, et al. Effect of endothelin-A receptor blockade with atrasentan on tumor progression in men with hormone-refractory prostate cancer: a randomized, phase II, placebo-controlled trial. J Clin Oncol 2003;21(4):679-89

69. Zonnenberg BA, Groenewegen G, Janus TJ, et al. Phase I dose-escalation study of the safety and pharmacokinetics of atrasentan: an endothelin receptor antagonist for refractory prostate cancer. Clin Cancer Res 2003;9(8):2965-72

70. Ferreira SH, Romitelli M, de Nucci G. Endothelin-1 participation in overt and inflammatory pain.

J Cardiovasc Pharmacol 1989;13(Suppl 5):S220-2

71. Raffa RB, Schupsky JJ, Martinez RP, Jacoby HI. Endothelin-1-induced nociception. Life Sci 1991;49(11):PL61-5 


\section{Anti-endothelin drugs in solid tumors}

72. Khodorova A, Navarro B, Jouaville LS, et al. Endothelin-B receptor activation triggers an endogenous analgesic cascade at sites of peripheral injury. Nat Med 2003;9(8):1055-61

73. Nelson JB. Endothelin receptor antagonists. World J Urol 2005;23(1):19-27

74. Nelson JB, Nabulsi AA, Vogelzang NJ, et al. Suppression of prostate cancer induced bone remodeling by the endothelin receptor A antagonist atrasentan. J Urol 2003;169(3):1143-9

75. Takuwa Y, Ohue Y, Takuwa N, Yamashita K. Endothelin-1 activates phospholipase $\mathrm{C}$ and mobilizes $\mathrm{Ca} 2+$ from extra- and intracellular pools in osteoblastic cells. Am J Physiol 1989;257(6 Pt 1):E797-803

76. Carducci MA, Saad F, Abrahamsson PA, et al. A phase 3 randomized controlled trial of the efficacy and safety of atrasentan in men with metastatic hormone-refractory prostate cancer. Cancer 2007;110(9):1959-66

77. Nelson JB, Love W, Chin JL, et al. Phase 3, randomized, controlled trial of atrasentan in patients with nonmetastatic, hormone-refractory prostate cancer. Cancer 2008;113(9):2478-87
78. Michaelson MD, Kaufman DS, Kantoff P, et al. Randomized phase II study of atrasentan alone or in combination with zoledronic acid in men with metastatic prostate cancer. Cancer 2006;107(3):530-5

79. Armstrong AJ, Creel P, Turnbull J, et al. A phase I-II study of docetaxel and atrasentan in men with castration-resistant metastatic prostate cancer. Clin Cancer Res 2008;14(19):6270-6

80. Chiappori AA, Haura E, Rodriguez FA, et al. Phase I/II study of atrasentan, an endothelin A receptor antagonist, in combination with paclitaxel and carboplatin as first-line therapy in advanced non-small cell lung cancer. Clin Cancer Res 2008;14(5):1464-9

81. James ND, Caty A, Borre M, et al. Safety and efficacy of the specific endothelin-A receptor antagonist ZD4054 in patients with hormone-resistant prostate cancer and bone metastases who were pain free or mildly symptomatic: a double-blind, placebo-controlled, randomised, phase 2 trial. Eur Urol 2009;55(5):1112-23

82. Schelman WR, Liu G, Wilding G, et al. A phase I study of zibotentan (ZD4054) in patients with metastatic, castrate-resistant prostate cancer. Invest New Drugs 2009, doi: 10.1007/s10637-009-9318-5

83. Kefford R, Beith JM, Van Hazel GA, et al. A phase II study of bosentan, a dual endothelin receptor antagonist, as monotherapy in patients with stage IV metastatic melanoma. Invest New Drugs 2007;25(3):247-52

\section{Affiliation}

Antonio Russo $^{\dagger 1} \mathrm{MD}$, Giuseppe Bronte ${ }^{1}$, Sergio Rizzo ${ }^{1}$, Daniele Fanale ${ }^{1}$, Francesca Di Gaudio ${ }^{2}$, Nicola Gebbia ${ }^{1}$ \& Viviana Bazan ${ }^{1}$

${ }^{\dagger}$ Author for correspondence

${ }^{1}$ Università di Palermo,

Section of Medical Oncology,

Department of Surgical and

Oncological Sciences,

Via del Vespro 129,

90127 Palermo, Italy

Tel: +39 091 6552500; Fax: +39 091 6554529;

E-mail: lab-oncobiologia@usa.net

${ }^{2}$ Professor,

Università di Palermo,

Department of Medical Biotechnology and Legal Medicine,

Palermo, Italy 